\title{
Genetic Variation and Variation in Aggressiveness to Native and Exotic Hosts Among Brazilian Populations of Ceratocystis fimbriata
}

\author{
Thomas C. Harrington, Daniel J. Thorpe, and Acelino C. Alfenas
}

First and second authors: Department of Plant Pathology, Iowa State University, Ames 50011; and third author: Departmento de Fitopatologia, Universidade Federal de Viçosa, Minas Gerais, Brazil. Current address of D. J. Thrope: Pioneer Hi-Bred International, Inc., Johnston, IA 50131. Accepted for publication 21 December 2010.

\begin{abstract}
Harrington, T. C., Thorpe, D. J., and Alfenas, A. C. 2011. Genetic variation and variation in aggressiveness to native and exotic hosts among Brazilian populations of Ceratocystis fimbriata. Phytopathology 101:555566.

Ceratocystis fimbriata is a complex of many species that cause wilt and cankers on woody plants and rot of storage roots or corms of many economically important crops worldwide. In Brazil, C. fimbriata infects different cultivated crop plants that are not native to Brazil, including Gmelina arborea, Eucalyptus spp., Mangifera indica (mango), Ficus carica (fig), and Colocasia esculenta (inhame). Phylogenetic analyses

there was little resolution of lineages based on these sequences. A portion of the MAT1-2 mating type gene showed less variation, and this variation corresponded more closely with host of origin. However, mango isolates were found scattered throughout the tree. Inoculation experiments on the five exotic hosts showed substantial variation in aggressiveness within and among pathogen populations. Native hosts from the same families as the exotic hosts tended to be less susceptible than the cultivated hosts, but there was little correlation between aggressiveness to the cultivated and native hosts of the same family. Cultivation and vegetative propagation of exotic crops may select for strains that are particularly aggressive on those crops.
\end{abstract} and inoculation studies were performed to test the hypothesis that there are host-specialized lineages of $C$. fimbriata in Brazil. The internal transcribed spacer region ribosomal DNA sequences varied greatly but
Additional keywords: C. cacaofunesta, C. manginecans, C. platani, host specialization.
The fungal plant pathogen Ceratocystis fimbriata Ellis \& Halst. has been thought to have a broad geographic and host range, including numerous plant families in over 41 countries spanning the six inhabited continents (2). However, C. fimbriata sensu lato is now recognized as a complex of many fungal species. Four phylogenetic clades within the complex include the Latin American clade, the North American clade, the Asian clade, and the African species C. albifundus M. J. Wingf., De Beer, \& M. J. Morris and its relatives $(9,15,17,29,32)$. Numerous species in these clades are important plant pathogens that cause wilting and cankering of cultivated woody plants or a dry, black rot of Ipomoea batatas (sweet potato) and Colocasia esculenta (inhame or taro) (2), though some of the species are wound colonizers on native plant hosts $(9,10,17)$. Substantial variation in the level of aggressiveness to both exotic and native hosts has been shown with some members of the complex $(1,17,20,32)$. A few phylogenetic lineages in the complex have been shown to be uniquely pathogenic to a native host, with an apparent loss of aggressiveness to other hosts, and such host specialization has been the phenotypic basis for description of some new species $(6,17)$.

Baker et al. (1) found that isolates collected from sweet potato, Theobroma cacao (cacao), and Platanus spp. (American sycamore and plane tree) were distinct from each other based on ribosomal DNA (rDNA) sequences and host range, and intersterility among these groups helped to justify recognition of these species as Ceratocystis fimbriata sensu stricto, C. cacaofunesta Engelbr. \& T. C. Harr., and C. platani (J. M. Walter) Engelbr. \& T. C. Harr., respectively (6). The sweet potato pathogen appears to

Corresponding author: T. C. Harrington; E-mail address: tcharrin@iastate.edu

doi:10.1094/PHYTO-08-10-0228

(C) 2011 The American Phytopathological Society be a single genotype of the fungus from South America that has been moved around the world on storage roots used for propagation (6). The cacao pathogen is believed to be a wound colonizer on native T. cacao in the Upper Amazon $(4,5)$, and $C$. platanti can be an aggressive wound pathogen on American sycamore (Platanus occidentalis) in the southeastern United States (7). With both C. cacaofunesta and C. platani, natural selection may have led to a change from a generalist wound colonizer with a wide variation in aggressiveness against a broad range of hosts to a more specialized and virulent pathogen on a single native host or group of related hosts, as has been suggested for other plant pathogens (24). Strains of both $C$. cacaofunesta and $C$. platani have been introduced accidentally to other regions and continents, resulting in substantial mortality on the specialized hosts and their relatives, especially on cacao cultivars from the Lower Amazon and on oriental plane (P. orientalis) and its hybrids $(P . \times$ acerifolia, London plane), respectively $(4,5,7,23)$.

The country of Brazil and the state of São Paulo arguably contain the greatest diversity of susceptible plant species and the most severe economic losses due to $C$. fimbriata (2). All Brazilian isolates from the complex fall within the Latin American clade $(8,9)$. With the exception of isolates of $C$. cacaofunesta, Ferreira et al. (8) proposed that Brazilian isolates be recognized as a single species, $C$. fimbriata, in part due to the interfertility of Brazilian isolates with isolates from sweet potato, the host from which $C$. fimbriata was originally described. Other recently described species in the Latin American clade include $C$. fimbriatomima M. van Wyk \& M. J. Wingf. from Venezuela (36) and C. colombiana M. van Wyk \& M. J. Wingf., C. neglecta M. van Wyk, Jol. Roux $\&$ Rodas, and C. papillata M. van Wyk \& M. J. Wingf. from Colombia $(26,35)$. Some of these new species can cause important diseases on cultivated crops but their native hosts are not well known, and they have not been fully characterized by inocu- 
lation studies. However, based on lesion size and mortality, a wide range in aggressiveness to coffee (Coffea arabica) was found among Colombian isolates of the complex, which are also known to attack Citrus spp. and native woody species that are used to provide shade to cultivated coffee plants (20). A recently described species from Mangifera indica (mango) in Oman and Pakistan, Ceratocystis manginecans M. van Wyk, A. Adawi \& M. J. Wingf., is also a member of the Latin American clade (34), though this name may be based on an introduced strain of $C$. fimbriata from Brazil (8).

Some of the species in the $C$. fimbriata complex have been associated with insect vectors such as nitidulids and bark beetles (Coleoptera: Nitidulidae and Curculionidae: Scolytinae, respectively), and others are known to be dispersed in the frass of ambrosia beetles (Curculionidae: Scolytinae and Platypodinae) that bore into the sapwood of diseased trees $(10,17)$. Dispersal in ambrosia beetle frass and soil or water infestation appear to be important for members of the Latin American clade $(1,4,16,23)$, which may be soilborne and infect roots or corms $(18,20,27)$. Cultivation of crops in infested soil may select for strains that are particularly aggressive on that crop $(8,20)$. Movement of the pathogen by humans in vegetatively propagated host material, in soil of nursery plants, or in beetle-infested wood are important pathways for long-distance dispersal $(8-10,27)$. All members of the complex are homothallic due to unidirectional mating type switching $(11,38)$; therefore, even sexually reproducing populations may be essentially clonal due to selfing, the predominant means of sexual reproduction (8). Populations derived from introductions on propagative material may be genetically uniform $(5,8,23)$. Geographically isolated populations in Brazil tend to be genetically differentiated, presumably due to limited dispersal distance on insects or in frass, selfing, and selection for aggressiveness on a particular cultivated crop (8). Although rDNA sequences and allozymes of isolates from the Latin American clade of the $C$. fimbriata complex have shown limited variation compared with isolates from the North American and Asian clades $(1,17,32)$, there may be substantial genetic variation among Latin American populations of the $C$. fimbriata complex based on mitochondrial DNA markers, randomly amplified polymorphic DNA, and simple sequence repeats of nuclear DNA $(5,7,8,20)$. A genetic study using microsatellite markers identified highly differentiated populations of $C$. fimbriata in Brazil, some of which were associated with a particular cultivated host (8). Isolates from inhame, Ficus carica (edible fig), and the Asian pulpwood species Gmelina arborea were unique based on microsatellite markers but Eucalyptus and mango isolates were more variable and were somewhat interrelated (8).

Ceratocystis wilt in Brazil is found primarily in the Mata Atlântica region, along the Atlantic coast from the states of São Paulo to Bahia, and in the Cerrado forest type of Minas Gerais (8). The genetic population structure of C. fimbriata in Brazil, or at least in São Paulo, Minas Gerais, Rio de Janeiro, and Bahia, suggests that the pathogen is native (8). All of the recognized susceptible hosts in these states are exotic to Brazil or at least exotic to the Mata Atlântica and Cerrado regions. Hosts of $C$. fimbriata in Brazil include Hevea spp. (rubber tree, native to the Amazon region), Eucalyptus spp., edible fig, Crotolaria juncea (sunn hemp), mango, Annona squamosa (sugar apple), and inhame $(2,8,14,30)$. G. arborea is a host of Ceratocystis fimbriata in the Lower Amazon region (22). To date, no isolates from native Brazilian hosts in their native range have been studied in detail. Cacao, a native of the Amazon region, is susceptible to a hostspecialized form of the $C$. fimbriata complex, C. cacaofunesta (6), which is native to the Upper Amazonian state of Rondônia and was recently introduced to Bahia $(4,5)$.

Different crop hosts seem to be affected in different regions of Brazil but limited host inoculation studies have failed to demonstrate host specialization. Brazilian isolates of $C$. fimbriata differ in host range from sweet potato isolates, C. cacaofunesta, and $C$. platani. Baker et al. (1) reported that sweet potato isolates of $C$. fimbriata were not pathogenic to mango or inhame, and the Brazilian isolates from mango, Eucalyptus, and Gmelina spp. were not pathogenic to sweet potato, cacao, or American sycamore. Also, C. cacaofunesta isolates were not pathogenic to mango, Eucalyptus, or Gmelina spp. (1). Ribeiro and Coral (25) also found that mango isolates from Brazil did not cause symptoms in cacao. Rather than clearly defined host specialization, Brazilian isolates of $C$. fimbriata have shown gradations in aggressiveness to various cultivated hosts based on the extent of xylem discoloration $(1,32)$, as was shown with inoculation of coffee plants with $C$. fimbriata isolates from Colombia (20).

The broad range of cultivated hosts in different regions of Brazil is surprising and suggests two alternative explanations. One explanation is that the pathogen is not specialized to any particular host. Instead, an individual isolate has the potential for a wide range of aggressiveness to various hosts due to numerous quantitative genetic traits, as reviewed by Pariaud et al. (24). Isolates from natural populations would show variation in aggressiveness to various hosts but recent cultivation and vegetative propagation has selected for aggressiveness to exotic crop hosts in some of the populations. Alternatively, there may be cryptic species that are specialized to infect only certain native plants in Brazil, and isolates of these cryptic species may be particularly aggressive on cultivated hosts from the same family or genus of their native hosts.

We hypothesized that some populations of $C$. fimbriata in Brazil are host-specialized, cryptic species that infect only certain native hosts, and these cryptic species are also specialized to infect cultivated exotic hosts from the respective plant families of the native hosts. Isolates from different populations were phylogenetically studied using rDNA sequences of the internal transcribed spacer region (ITS-rDNA) and a portion of a matingtype gene (MAT1-2) to see if there were lineages or potential species from certain hosts. New species might be recognized if the lineages were shown to have a unique phenotype, such as host range (13); therefore, representative isolates from the various cultivated hosts were used in inoculation studies to see if they were specialized to particular cultivated hosts. Further, we tested to see whether isolates from exotic crop plants were aggressive to native Brazilian plants in the respective families of the exotic hosts.

\section{MATERIALS AND METHODS}

Fungal isolates. Isolates were collected from diseased trees in the field or, in the case of inhame, from corms with symptoms of black rot in grocery stores or markets. The fungus was baited out from diseased wood or rotted corm tissue by placing pieces of diseased tissue between two discs of carrot (21). Ascospore masses from perithecia forming on the carrots were transferred to malt yeast extract agar (MYEA) (2\% malt extract, $2 \%$ agar, and $0.2 \%$ yeast extract), and pure cultures were stored in glycerol at $-80^{\circ} \mathrm{C}$. All isolates used in inoculation studies were singleascospore strains. Most of the isolates used in inoculation studies were collected in 1998 to 2002 but the G. arborea isolates were collected in 1996 and mango isolate C994 was deposited in the Centraalbureau voor Schimmelcultures in 1970.

Sixty-one isolates from five cultivated hosts ( $G$. arborea, fig, inhame, Eucalyptus spp., and mango) were selected from different populations of $C$. fimbriata across Brazil for ITS-rDNA sequencing (Table 1). All isolates were from separate plants and most were from separate farms or plantations, though the Gmelina isolates were from a small section of a single plantation (8). A smaller set of 29 Brazilian isolates from the five cultivated hosts were selected for sequencing a portion of the MATl-2 gene. Three isolates from each cultivated host were used in inoculation studies. 
DNA extraction and DNA sequencing. Two methods were used to obtain genomic DNA from cultures for use as template in polymerase chain reactions (PCR). In one method, mycelium was grown in $25 \mathrm{ml}$ of liquid medium (2\% malt extract and $0.2 \%$ yeast extract) at room temperature for 2 weeks; and DNA extraction followed the method of DeScenzo and Harrington (3). Another method used the Prepman Ultra kit (Applied Biosystems, Foster City, CA) to extract DNA from mycelia, conidia, and perithecia scraped from the surface of plates of MYEA after 1 week of growth at room temperature.

Sequences of the ITS region, including the 5.8S gene, were obtained by PCR amplification from genomic DNA using the primers ITS1F and ITS4 following the protocol of Harrington et al. (12), with slightly different cycling conditions: initial denaturation at $94^{\circ} \mathrm{C}$ for $95 \mathrm{~s}$ followed by 35 cycles of denaturation at $94^{\circ} \mathrm{C}$ for $35 \mathrm{~s}$, annealing at $52^{\circ} \mathrm{C}$ for $60 \mathrm{~s}$, and extension at $72^{\circ} \mathrm{C}$ for $60 \mathrm{~s}$. Final extension was at $72^{\circ} \mathrm{C}$ for $15 \mathrm{~min}$. The MAT1-2 gene region $(37,38)$ was amplified with primers CFM21F (5'-AGTTACAAGTGTTCCCAAAAG-3') and X9978R1R (5'GCTAACCTTCACGCCAATTT- $3^{\prime}$ ), and a product of $\approx 1,150 \mathrm{bp}$ was obtained with all isolates. Complementary sequences of the PCR products were obtained with the PCR primers at the Iowa State University DNA Sequencing and Synthesis Facility.

Phylogenetic analysis. Sequences of $C$. fimbriata isolates from Brazil were compared with each other using parsimony analysis (31). An isolate of C. fimbriata (C1418, North Carolina) from sweet potato and representatives of two other species in the Latin
American clade, C. platani (C1317, North Carolina) and $C$. cacaofunesta (C1587, Bahia, Brazil), were also included (6). A Hawaiian Colcasia esculenta isolate (C1715) of an undescribed Ceratocystis sp. in the Asian clade of the Ceratocystis fimbriata complex (32) was used as the outgroup taxon in both the ITSrDNA and MAT1-2 analyses. This undescribed species was selected as the outgroup taxon because its ITS-rDNA and MAT1-2 sequences were the most similar and most easily aligned to those of the Latin American clade (32).

The 65 ITS-rDNA sequences were aligned manually by adding gaps. There were many short insertion-deletions (indels) among the Brazilian isolates. Gaps were treated as a fifth character. Of the 587 total aligned characters, including gaps, 12 were ambiguously aligned and excluded from the analysis, 107 remaining sites were variable, and, of these, 40 were parsimony informative. A maximum parsimony heuristic search was performed with all characters having equal weight. Stepwise addition was used to obtain starting trees, and tree-bisection-reconnection was used. Bootstrap analysis with 1,000 replications of heuristic searches was used to assess support for the internal branches.

The 33 MAT1-2 sequences were aligned manually by adding gaps but there was no gap among the ingroup taxa. Of the 1,133 total characters, 176 sites were variable and, of these, only 19 were parsimony informative. A maximum parsimony heuristic search was performed with all characters having equal weight. Bootstrap analysis with 1,000 replications of heuristic searches was used to assess support for the internal branches.

TABLE 1. Host, state of origin, population, internal transcribed spacer ribosomal DNA (ITS-rDNA) and MAT1-2 haplotypes, and GenBank accession numbers of representative DNA sequences of Brazilian Ceratocystis fimbriata isolates used in phylogenetic analyses and inoculation studies

\begin{tabular}{|c|c|c|c|c|c|c|c|}
\hline Host plant & State of origin & Population $^{w}$ & Isolate numbers ${ }^{\mathrm{x}}$ & $\begin{array}{c}\text { ITS } \\
\text { haplotype }^{y}\end{array}$ & $\begin{array}{l}\text { ITS GenBank } \\
\text { accession no. }\end{array}$ & $\begin{array}{c}\text { MAT1-2 } \\
\text { haplotype }^{\mathrm{z}}\end{array}$ & $\begin{array}{c}\text { MAT1-2 } \\
\text { GenBank } \\
\text { accession no. }\end{array}$ \\
\hline Gmelina arborea & Pará & GmePA & C918*, C920*, C925* (= CBS 115173) & 15 & AY157967 & 1 & HQ157549 \\
\hline \multirow[t]{5}{*}{ Colocasia esculenta } & São Paulo & ColsP2 & C1914 & 9 & HQ157540 & NT & $\ldots$ \\
\hline & $\ldots$ & $\ldots$ & C1926* & 12 & HQ157541 & 5 & $\ldots$ \\
\hline & $\ldots$ & $\ldots$ & C1907 & 12 & $\ldots$ & 6 & $\ldots$ \\
\hline & $\ldots$ & $\ldots$ & C1916 & 12 & & NT & $\ldots$ \\
\hline & Rio de Janeiro & NT & C1865* (= CBS 114713) & 11 & AY526286 & 5 & $\ldots$ \\
\hline \multirow[t]{4}{*}{ Ficus carica } & São Paulo & FicSP3 & $\mathrm{C} 1857^{*}, \mathrm{C} 1858, \mathrm{C} 1899^{*}$ & 1 & HQ157542 & 4 & $\ldots$ \\
\hline & $\ldots$ & $\ldots$ & C1852, C1853, C1856, C1895 & 1 & & NT & $\ldots$ \\
\hline & $\ldots$ & $\ldots$ & C1782* (= CBS 115166$),$ C1783 & 8 & AY526292 & 4 & $\ldots$ \\
\hline & $\ldots$ & $\ldots$ & C1848-1851, C1854-C1855 & 8 & $\ldots$ & NT & $\ldots$ \\
\hline \multirow[t]{5}{*}{ Eucalyptus spp. } & Bahia & EucBA1 & C2015 & 3 & $\ldots$ & NT & $\ldots$ \\
\hline & $\ldots$ & $\ldots$ & C1985 & 5 & $\ldots$ & 3 & $\ldots$ \\
\hline & $\ldots$ & $\ldots$ & C1450 & 4 & & NT & $\ldots$ \\
\hline & $\ldots$ & $\ldots$ & C1345* & 5 & AY157966 & 3 & $\ldots$ \\
\hline & Paraná & NT & C1987 & NT & $\ldots$ & 5 & $\ldots$ \\
\hline \multirow[t]{11}{*}{ Mangifera indica } & São Paulo & ManSP1 & C1655 & 2 & HQ157546 & NT & $\ldots$ \\
\hline & $\ldots$ & $\ldots$ & C1656 & 6 & $\ldots$ & NT & $\ldots$ \\
\hline & $\ldots$ & $\ldots$ & C1889 & 7 & HQ157547 & 3 & $\ldots$ \\
\hline & $\ldots$ & $\ldots$ & C994* (= CBS 600.70), C1847 & 10 & EF042605 & 4 & HQ157551 \\
\hline & $\ldots$ & $\ldots$ & $\mathrm{C} 1657$ & 14 & & NT & $\ldots$ \\
\hline & $\ldots$ & $\ldots$ & C1688* (= CBS 114721) & 14 & AY526291 & 3 & $\ldots$ \\
\hline & Rio de Janeiro & ManRJ1 & C2055, C2057 & 6 & HQ157548 & 3 & $\ldots$ \\
\hline & $\ldots$ & ManRJ2 & $\mathrm{C} 1558^{*}(=\mathrm{CBS} 115175), \mathrm{C} 1590$ & 9 & AY157965 & 5 & HQ157552 \\
\hline & $\ldots$ & $\ldots$ & $\mathrm{C} 1554, \mathrm{C} 1557, \mathrm{C} 1589, \mathrm{C} 2112$ & 9 & $\ldots$ & NT & \\
\hline & Pernambuco & NT & C1968 & NT & $\ldots$ & 2 & HQ157553 \\
\hline & $\ldots$ & NT & C1970 & NT & $\ldots$ & 3 & $\ldots$ \\
\hline
\end{tabular}

${ }^{\text {w }}$ Population designation based on microsatellite alleles as determined in Ferreira et al. (8). The first three letters indicate the host of origin, followed by the abbreviation for the state of origin. NT $=$ not tested.

${ }^{\mathrm{x}}$ Isolates numbers are those of the collection of T. C. Harrington, Iowa State University and equivalent numbers in the Centraalbureau voor Schimmelcultures (CBS). Numbers followed by an asterisk designate isolates used in inoculation studies.

${ }^{y}$ Haplotypes were unique ITS-rDNA sequences as shown in Figure $1 . \mathrm{NT}=$ not tested.

${ }^{\mathrm{z}}$ Haplotypes were unique MAT1-2 sequences as shown in Figure 2. NT $=$ not tested. 
Pathogenicity tests. Three representative isolates from each of the five exotic Brazilian hosts (Table 1) were used in inoculation experiments in an outdoor nursery in Brazil (in November 2002) and in growth chambers at Iowa State University.

Nursery experiment. One inoculation experiment was performed during the summer at an outdoor nursery at the Universidade Federal de Viçosa, Minas Gerais. Sixteen plant species, including the 5 exotic hosts, the exotic Pimenta officinalis (allspice or pimento), and 10 relatives native to Brazil, were used. In the Verbenaceae family, the exotic host was $G$. arborea (6-month-old seedlings) and the native hosts were Citharexylum myrianthum (6-month-old seedlings), Duranta erecta (6-monthold seedlings), and Lantana camara (8-month-old seedlings). In the Araceae family, the exotic hosts were inhame (2-month-old plants from corms) and Colocasia esculenta 'Fontanesii' (2-month-old plants from corms), and the native host was Spathiphyllum wallisii (3-month-old rooted slips). In the Moraceae family the exotic host was the edible fig (6-month-old seedlings); no native hosts in the Moraceae family were included. In the Myrtaceae family, the exotic hosts were eucalyptus clones number 10 and 1172 of Eucalyptus grandis $\times$ E. urophylla ('urograndis,' 6-month-old cuttings) and allspice (6-month-old seedlings), and the native hosts included Eugenia uniflora (3-month-old seedlings), Psidium guajava (guava, 3-month-old seedlings), and $P$. cattleianum (3-month-old seedlings). In the Anacardiaceae family, the exotic host was mango (11-month-old seedlings) and the native hosts were Anacardium occidentale (cashew, 6-month-old seedlings) and Schinus terebinthifolius (6-month-old seedlings). All plants were grown in plastic bags or pots filled with soil. They were placed on benches that were covered by a clear, plastic tarp to exclude rain. The plants were watered daily.

Inoculum preparation and inoculation procedures were as described by Baker et al. (1). A self-fertile (MAT-2 phenotype), single-ascospore strain of each isolate was transferred onto MYEA and grown at room temperature for 7 days. Inoculum was prepared by flooding each culture with $10 \mathrm{ml}$ of sterile, distilled water (SDW), scraping the mycelium with a sterile spatula, and filtering the suspension through four layers of sterile cheesecloth, which was rinsed with an additional $5 \mathrm{ml}$ of SDW. Spore concentration was estimated using a hemacytometer, diluted to $2.0 \times 10^{5}$ spores $/ \mathrm{ml}$ with SDW, and loaded into sterile syringes (needle gauge 21). Spore suspensions consisted almost entirely of cylindrical endoconidia, although there were some ascospores and hyphal fragments. Controls were prepared following the same technique using a sterile MYEA plate.

Woody plants were wounded by making an $\approx 3$-mm-deep, downward-slanting cut from the outer bark into the wood with a sterile scalpel, $\approx 3 \mathrm{~cm}$ above the soil line. Because the stems of the $G$. arborea seedlings were soft, wounds were created by the sterile syringe, punched into the stem at $\approx 3 \mathrm{~cm}$ above the soil line. The pseudopetiole of the youngest, fully expanded leaf of each Araceae plant was similarly wounded with the sterile syringe. At least $0.2 \mathrm{ml}$ of spore suspension was injected into each wound using the sterile syringe, and the inoculation site was wrapped with Parafilm. The inoculated plants were monitored daily for death or wilting. After 23 to 24 days, each stem or pseudopetiole was sliced open vertically above and below the point of inoculation, and the length of xylem discoloration was measured.

Growth-chamber experiments. Plants inoculated in growth chambers included G. arborea, D. erecta, L. camara, inhame, fig, and $A$. occidentale. $G$. arborea plants were grown for 8 to 9 months from seed purchased from Lawyer Nursery Inc. (Plains, MT); D. erecta and L. camara plants were grown for 5 to 6 months from seedlings purchased from Bill Moore \& Co., Inc. (Brandon, FL); inhame plants were grown for 2 months from corms purchased from various grocery stores in Ames and Des Moines, IA; fig plants were grown for 10 to 11 months from seed provided by James Doyle (Kearney Agricultural Center, Parlier, $\mathrm{CA}$ ); and A. occidentale plants were grown for 4 to 5 months from seed purchased from B \& T World Seeds (Aigues-Vives, France). Prior to inoculations, all plants were grown in pasteurized potting mix (25\% peat, $25 \%$ soil, and $50 \%$ perlite) in a greenhouse in full sun, with a maximum daily temperature of $\approx 25^{\circ} \mathrm{C}$. The plants were adequately watered and fertilized $(25 \%$ Peter's Excel 21-5-20, 75\% Peter's Cal-Mag Special 15-5-15) weekly.

Seven days prior to inoculation, plants were placed in a growth chamber set at $25^{\circ} \mathrm{C}$ with a light-and-dark cycle of 16 and $8 \mathrm{~h}$, respectively, with photosynthetically active radiation at $\approx 95 \mu \mathrm{mol}$ $\mathrm{cm}^{-2} \mathrm{~s}^{-1}$. Plants were well watered in the growth chamber prior to and during inoculation experiments. These plants were inoculated using the methods described above. Length of discoloration was recorded after 4 weeks. To reisolate the fungus, discolored tissue was placed between two carrot discs and incubated under humid conditions at room temperature. After 7 to 14 days, the carrot discs were observed for growth of Ceratocystis fimbriata.

Experimental design and statistical analyses. The nursery experiment had four to six replications of each treatment in a completely randomized design for each species of plant. For a few host species with a limited number of plants, some isolates were omitted. In the growth-chamber experiments, two separate experiments were performed on each host, with three replications (G. arborea and A. occidentale), four replications (fig), or five replications of each treatment in a completely randomized design for each experiment.

Data on the length of xylem discoloration were analyzed using a multifactorial analysis of variance (ANOVA) including isolate, source (host) of inoculum, and experiment. Data from the two growth-chamber experiments on each host were combined if there was homogeneity of variances; otherwise, the data from the two experiments were analyzed separately. When ANOVA indicated significant variation among isolates and controls $(P \leq 0.05)$, the Fisher's protected least significant difference (LSD) test was used to make pairwise mean comparisons among the treatments, including the controls. Percent mortality was compared between each isolate and the control using Fisher's Exact Test adjusted for multiple comparisons by the Bonferroni method. All statistics were performed using SAS statistical software (SAS Institute, Cary, NC).

\section{RESULTS}

Phylogenetic analysis. A single most-parsimonious tree of 178 steps was derived from the 40 parsimony-informative characters from the total ITS aligned dataset. The ITS sequences of the isolates from Brazil varied greatly but were similar to those of other species in the Latin American clade (C. fimbriata sensu stricto, C. platani, and C. cacaofunesta) (Fig. 1). There were 16 ITS haplotypes found among $C$. fimbriata isolates from Brazil. Differences among the haplotypes were mostly due to indels of 3 to $6 \mathrm{bp}$ each. Isolates from each of the five exotic hosts had at least two ITS haplotypes (Table 1). The Gmelina isolate C924 had a slightly different ITS sequence from the other Gmelina isolates. Eucalyptus isolates had one of three ITS haplotypes. Mango isolates showed the greatest diversity of ITS sequences (six haplotypes), and fig isolates had two different ITS haplotypes (Fig. 1; Table 1). The fig isolates from the population FicSP3 in São Paulo showed almost no variation in microsatellite markers (8) but had two distinct ITS haplotypes (Fig. 1). The inhame isolates had four different ITS haplotypes (Fig. 1).

Some isolates from different hosts had the same ITS sequence. The branch of haplotype ITS9, which had moderate bootstrap support (Fig. 1), contained an isolate from inhame and six isolates from mango. There was little resolution of the relationships among the ITS haplotypes; that is, there was little or no bootstrap 
support for branches connecting two or more ITS haplotypes (Fig. 1). The representatives of $C$. fimbriata sensu stricto, $C$. platani, and $C$. cacaofunesta did not group with bootstrap support with any of the Brazilian isolates of $C$. fimbriata.

Of the 1,133 total characters from the aligned MAT1-2 dataset, 176 sites were variable but, of these, only 19 were parsimony informative. The MAT1-2 analysis showed a limited number of haplotypes; there were more groupings among the haplotypes (Fig. 1), and most isolates from a given microsatellite population
(8) had an identical MAT1-2 sequence (Table 1). However, mango isolates fell into four different MAT1-2 lineages, and the ManSP1 population had two different haplotypes (Fig. 2). Two Bahian populations of isolates from Eucalyptus had the identical MAT1-2 sequence, which was identical to that of some of the mango isolates, but the Eucalyptus isolate from Paraná had the same MAT1-2 sequence as the mango isolates from northeastern Rio de Janeiro (population ManRJ2) and the inhame isolates (Fig. 2). The fig isolates had a MAT1-2 sequence identical to that of two

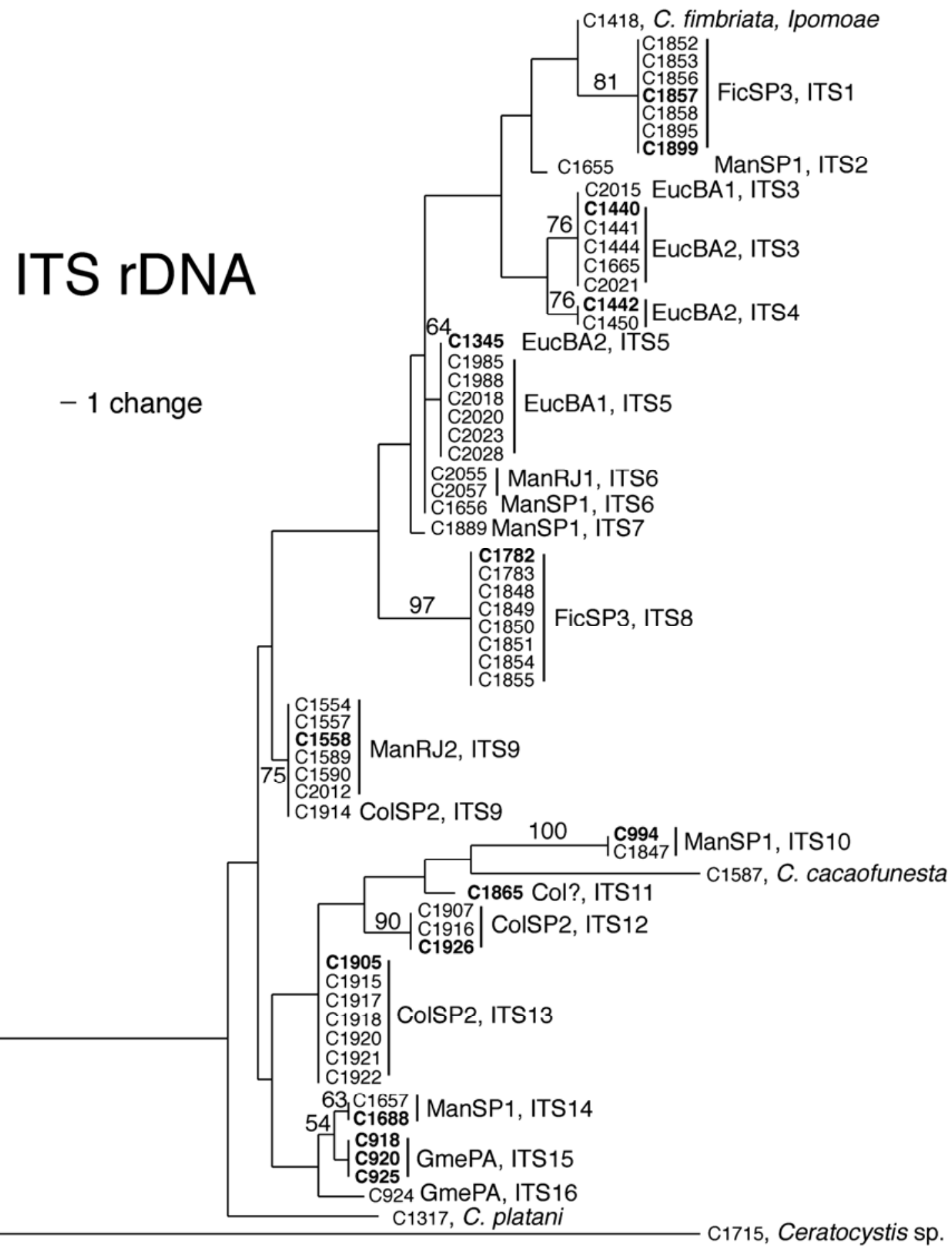

Fig. 1. Single most parsimonious tree of 178 steps using 575 aligned characters of internal transcribed spacer ribosomal DNA (ITS-rDNA) sequences of Ceratocystis fimbriata isolates from Brazil. Sequences of a sweet potato isolate of C. fimbriata, C. cacaofunesta, and C. platani were also included. Isolate C1715 of an unidentified Ceratocystis sp. from Colocasia esculenta in Hawaii (32) was used as the outgroup taxon. The consistency index, retention index, and rescaled consistency index were $0.6629,0.9002$, and 0.5967 , respectively. Bootstrap values $>50$ are shown above the branches. Numbers in bold designate isolates used in inoculation studies. Population designations based on microsatellite alleles (8) are shown to the right. Designation of ITS-rDNA haplotype (unique ITS-rDNA sequence) is also shown. 
mango isolates from population ManSP1. The Gmelina isolates had a unique MATI-2 sequence, and this lineage had $86 \%$ bootstrap support. There was moderate support (84\% bootstrap support) for the branch containing the sweet potato strain and all the Brazilian isolates except those from populations ColSP2 and ManRJ2. There was weak support (59\%) for the branch containing all the Brazilian isolates and the sweet potato strain $(C$. fimbriata sensu stricto), and there was somewhat stronger support (78\%) for the branch that also included C. cacaofunesta (Fig. 2) but excluded $C$. platani.

Pathogenicity tests. Verbenaceae host plants. The ANOVA indicated that there was significant variation in the length of xylem discoloration among the isolates inoculated into the Gmelina plants, both in the nursery and in the growth-chamber experiments $(F=11.51, P<0.0001$ and $F=59.80, P<0.0001$, respectively). Only inoculations with Gmelina isolates C920 and C925 resulted in significant mortality in the growth chamber, and only the three Gmelina isolates (population GmePA, haplotype
ITS15) caused significantly greater xylem discoloration than the control inoculations in the nursery and growth-chamber experiments (Table 2). Six of the Gmelina plants died from breakage at the point of wound inoculation, and one other Gmelina plant, inoculated with inhame isolate C1905, also died. Successful reisolation of the fungus from Gmelina plants was $\geq 50 \%$ for all isolates in the growth-chamber experiments.

There was no mortality in any of the three native species of Verbenaceae. Two of the three Gmelina isolates (C918 and C920) generally caused significantly greater xylem discoloration than the controls in Citharexylum myrianthum and D. erecta but there was little difference among the isolates in the amount of discoloration in L. camara (Table 2). Data from the two inoculation experiments of $D$. erecta in the growth chamber could not be combined because the variances of the two experiments were not homogeneous. Xylem discoloration varied significantly by isolate $(F=26.22, P<0.0001)$ and experiment $(F=18.65, P<0.0001)$ and there was significant isolate-experiment interaction $(F=$

\section{MAT-2}

\begin{tabular}{|c|c|c|}
\hline & C918 & \\
\hline 86 & C920 & GmePA, ITS15 \\
\hline 6 & $\begin{array}{l}\text { C925 } \\
\text { C924 } \\
\text { C1968, }\end{array}$ & $\begin{array}{l}\text { GmePA, ITS } 16 \\
\text { Mangifera, Pernambuco }\end{array}$ \\
\hline 96 & $\begin{array}{l}\text { C1970, } \\
\text { C1688 } \\
\text { C1889 }\end{array}$ & $\begin{array}{l}\text { Mangifera, Pernambuco } \\
\text { ManSP1, ITS14 } \\
\text { ManSP1, ITS7 }\end{array}$ \\
\hline & $\begin{array}{l}\mathrm{C} 2055 \\
\mathrm{C} 2057\end{array}$ & |ManRJ1, ITS6 \\
\hline 6 & $\begin{array}{l}\text { C1985 } \\
\text { C1345 } \\
\text { C1347 } \\
\text { C1440 } \\
\text { C1442 }\end{array}$ & $\begin{array}{l}\text { EucBA1, ITS5 } \\
\text { EucBA2, ITS5 } \\
\text { EucBA2 } \\
\text { EucBA2, ITS3 } \\
\text { EucBA2, ITS4 }\end{array}$ \\
\hline
\end{tabular}

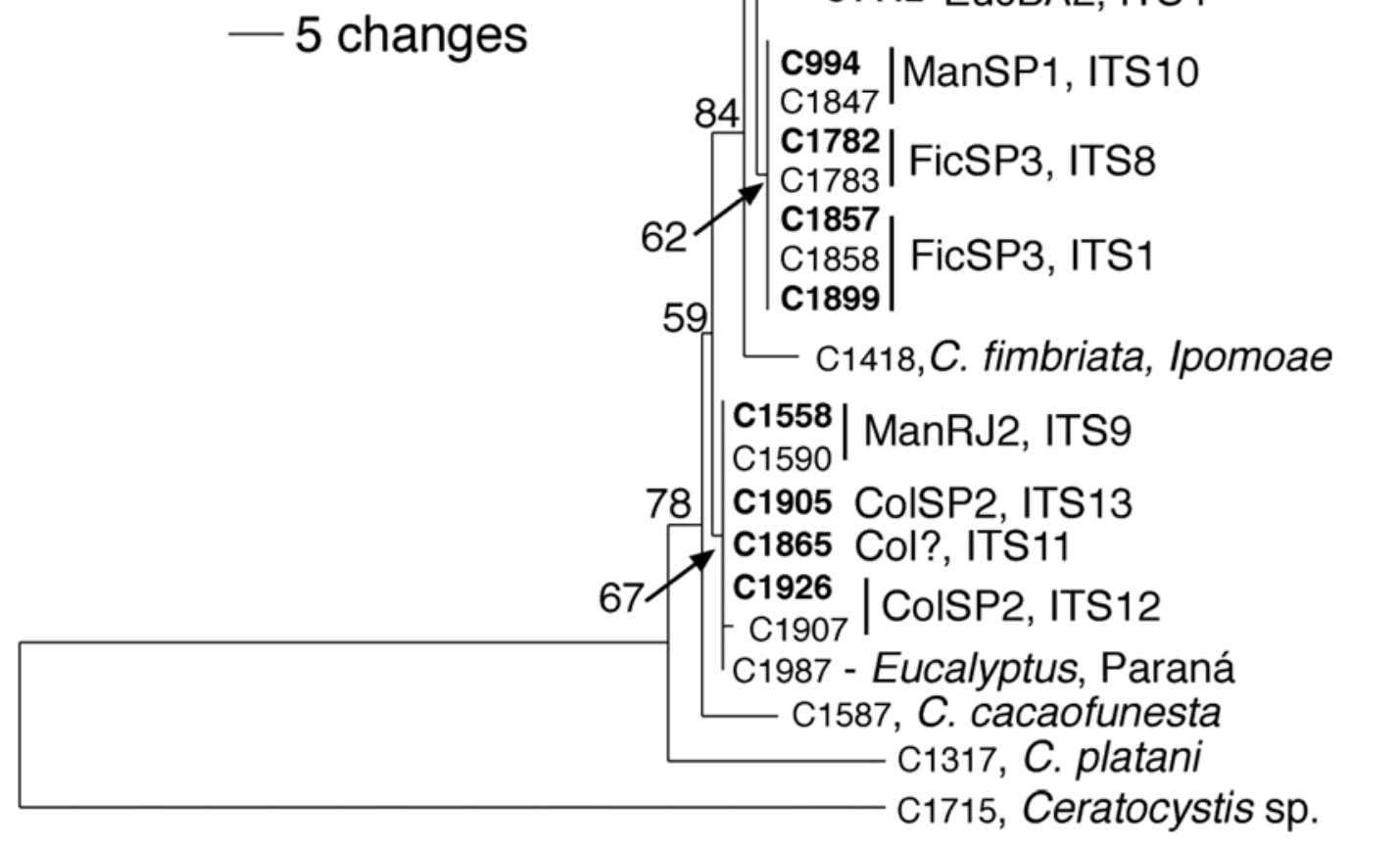

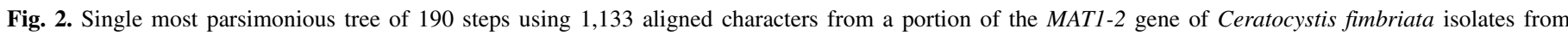

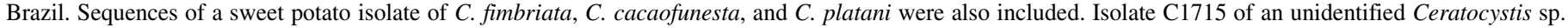

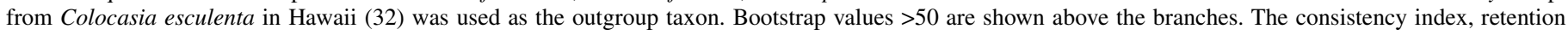

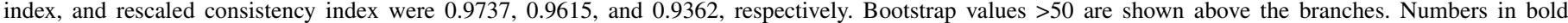

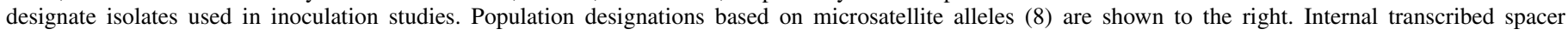
ribosomal DNA haplotypes (from Figure 1) are also shown. 
1.93, $P=0.026$ ). Similarly, data from the two experiments of $L$. camara in a growth chamber could not be combined because variances of the two experiments were not homogeneous. Xylem discoloration varied significantly by isolate $(F=4.45, P<$ $0.0001)$ and experiment $(F=4.51, P=0.036)$ and there was significant isolate-experiment interaction $(F=2.75, P=0.001)$. The fungus was not recovered from $D$. erecta and, from $L$. camara, reisolation was variable, with a range from $10 \%$ with Colocasia isolate C1865 to $70 \%$ with Eucalyptus isolates C1440 and $\mathrm{C} 1442$ and mango isolate C1558.

Araceae host plants. Inoculations of inhame plants resulted in a large percentage of pseudopetioles dying in the nursery $(0$ to $75 \%$ ) (Table 3) and in the growth-chamber experiments (60 to $90 \%$ ) but many of the control inoculations (70\%) also resulted in pseudopetiole mortality in the growth chamber. Natural senescence of pseudopetioles occurred at a much more rapid pace in the growth chamber than in the nursery, thus leading to high mortality rates.

Inhame isolates were generally among the most aggressive isolates on inhame plants in both the nursery and growth-chamber experiments (Table 3). ANOVA indicated that there was significant variation in the length of xylem discoloration caused by the isolates in the nursery inoculations $(F=2.83, P=0.0021)$, with isolates C1905 from inhame and C1345 from Eucalyptus causing the most extensive discoloration; however, discoloration was significantly greater than the control with all but four isolates (Table 3). Two inhame isolates, C1905 and C1865, caused the most mortality in the nursery experiment.

TABLE 2. Average length of xylem discoloration and percent mortality (Gmelina arborea only) in the exotic G. arborea and in native Brazilian Verbenaceae spp. (Citharexylum myrianthum, Duranta erecta, and Lantana camara) inoculated in nursery and growth-chamber experiments ${ }^{\mathrm{w}}$

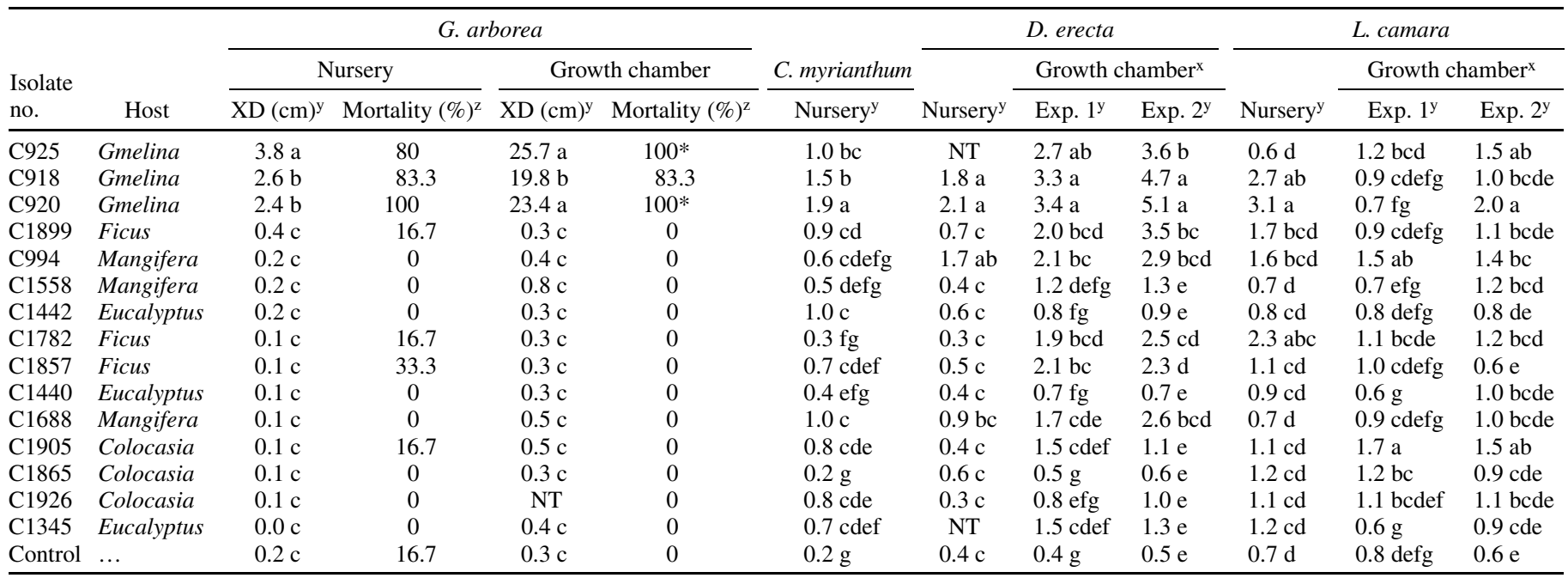

${ }^{\mathrm{w}} \mathrm{XD}=$ xylem discoloration, $\mathrm{NT}=$ the isolate was not tested.

x There was no homogeneity of variances for the first and second experiments; therefore, the data for the two experiments were analyzed separately.

${ }^{y}$ Numbers within a column followed by the same letter are not significantly different $(P<0.05)$ based on Fisher's protected least significant difference.

${ }^{z}$ Values of percent mortality within a column followed by an asterisk are significantly different $(P<0.05)$ from the control according to Fisher's exact test (Bonferroni adjusted $\alpha=0.0033$ ). Values of percent mortality for the nursery experiment did not significantly differ.

TABLE 3. Average length of xylem discoloration and percent mortality of the pseudopetiole in exotic Araceae spp. inoculated in nursery and growth-chamber (Colocasia esculenta only) experiments

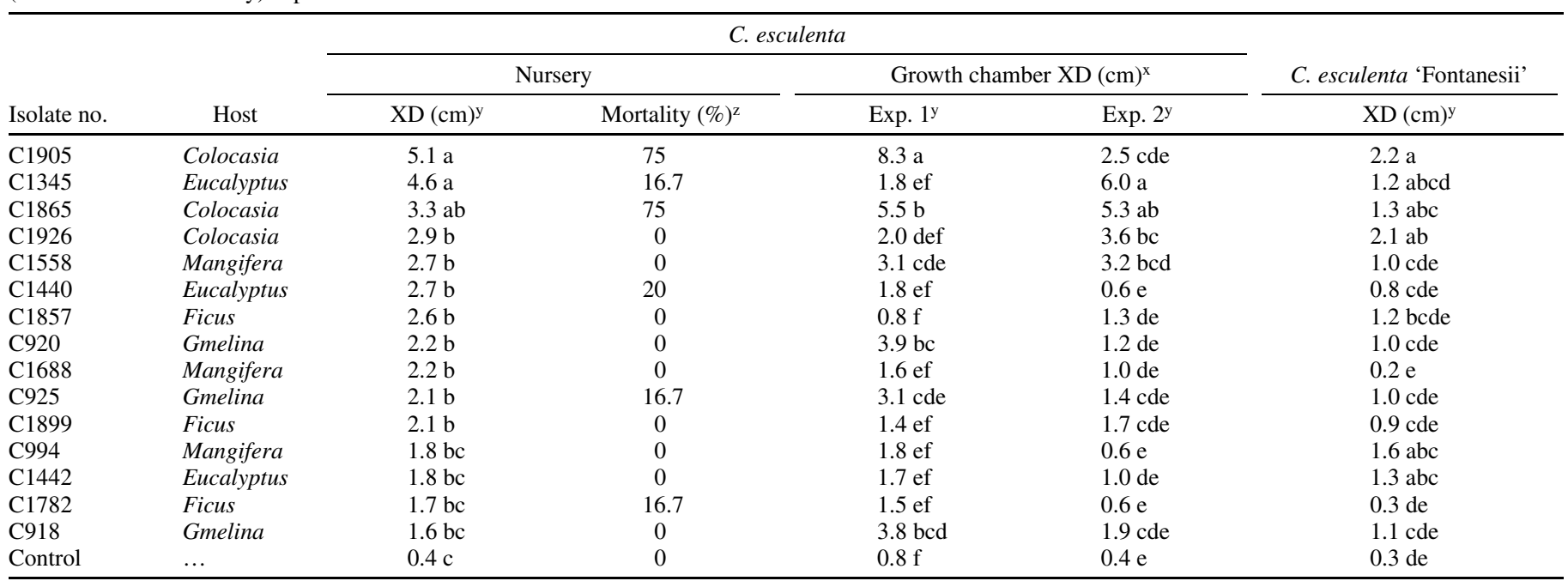

${ }^{\mathrm{x}} \mathrm{XD}=$ xylem discoloration. There was no homogeneity of variances for the first and second experiments; therefore, the data for the two experiments were analyzed separately.

y Numbers within a column followed by the same letter are not significantly different $(P<0.05)$ based on Fisher's protected least significant difference.

${ }^{\mathrm{z}}$ For the nursery experiment, values of percent mortality within a column were not significantly different $(P<0.05)$ according to Fisher's exact test $(B o n f e r r o n i$ adjusted $\alpha=0.0033$ ). There was substantial mortality of petioles of control plants in the growth-chamber experiments; therefore, mortality data are not shown. 
Xylem discoloration data from the two growth-chamber experiments could not be combined because the variances of the two experiments were not homogeneous. Xylem discoloration varied significantly by isolate $(F=8.19, P<0.0001)$ and experiment $(F=6.43, P=0.012)$ and there was significant isolate-experiment interaction $(F=3.91, P<0.0001)$. There was significant variation in the length of xylem discoloration among the isolates in both growth-chamber experiments $(F=8.79, P<0.0001$ and $F=4.28, P<0.0001)$. The isolate causing the greatest xylem discoloration in the nursery experiment and in growth-chamber experiment 1, C1905 from inhame, did not cause discoloration significantly greater than the control in experiment 2 . Also, the isolate causing the greatest xylem discoloration in experiment 2 , C1345 from Eucalyptus, did not cause discoloration significantly greater than the control in experiment 1. Reisolation of the pathogens was $>50 \%$ for all isolates except C920, C1440, C1782, and C1926.

Inoculations of Colocasia esculenta Fontanesii resulted in five isolates causing greater discoloration than the control. The ANOVA indicated significant variation in the length of xylem discoloration among the isolates $(F=2.41, P=0.0081)$ but the length of discoloration was $\leq 2.2 \mathrm{~cm}$. The native Araceae host, $S$. wallisii, showed significant variation in the length of xylem discoloration among the isolates $(F=2.54, P=0.0052)$ but the length of discoloration was $<1.0 \mathrm{~cm}$ with all isolates and the data are not shown.

Moraceae host plants. There was substantial discoloration and mortality in fig (Table 4). In both the nursery and growth-chamber experiments, there was significant variation in the length of xylem discoloration among the isolates $(F=2.23, P=0.0117$ and $F=$ $3.50, P<0.0001$, respectively), and the fig isolates were among the most aggressive. The three isolates from inhame, Eucalyptus isolate C1345, and mango isolate C1688 did not cause significantly greater xylem discoloration than the control in the nursery experiment. The two isolates causing the greatest discoloration were C918 from Gmelina and C1782 from fig.

Less discoloration was seen in the fig inoculated in growth chambers than in the nursery experiment, and there was no mortality in the growth-chamber experiments. All but four isolates (C1558 and C994 from mango, C1442 from Eucalyptus, and C1926 from inhame) caused significantly more xylem discoloration than the controls in the growth-chamber experiments. Successful reisolation of the pathogen was at least $50 \%$ for all isolates, and most isolates were isolated from all inoculated fig plants.
Myrtaceae host plants. Of the three exotic and three native host plants inoculated, only isolates inoculated into Eucalyptus hybrid 'urograndis' clone 1172 and Pimenta officinalis, a host of Ceratocystis fimbriata in Jamaica (19), caused significant variation in the length of xylem discoloration $(F=6.11, P<$ 0.0001 and $F=3.42, P=0.0003$, respectively) (Table 5). The native species of Myrtaceae (E. uniflora, Psidium guajava, and $P$. cattleianum) did not show significant variation in the length of xylem discoloration $(F=1.51, P=0.1293 ; F=1.63, P=0.0900$; and $F=1.35, P=0.2015$; respectively), and these data are not shown. There was no mortality in any of the inoculated Myrtaceae hosts.

Eucalyptus isolates $\mathrm{C} 1442$ and C1440 (population EucBA2; haplotypes ITS3 and ITS4, respectively) caused the greatest xylem discoloration in Eucalyptus clone 1172. Isolates C918 and C925 from Gmelina, C994 and C1688 from mango, and C1857 and C1899 from fig were not tested on Eucalyptus spp. Eucalyptus isolates $\mathrm{C} 1440$ and $\mathrm{C} 1442$ inoculated into Eucalyptus 'urograndis' clone 10 showed slightly greater xylem discoloration than other isolates but there was no overall significant variation in these values $(F=1.91, P=0.0991)$ and their data are not shown.

TABLE 5. Average length of xylem discoloration $(\mathrm{cm})$ in two exotic Myrtaceae spp. inoculated at a nursery with Brazilian isolates of Ceratocystis fimbriata $^{\mathrm{z}}$

\begin{tabular}{llcl}
\hline Isolate no. & \multicolumn{1}{c}{ Host } & $\begin{array}{c}\text { Eucalyptus 'urograndis' } \\
\text { clone } 1172\end{array}$ & $\begin{array}{c}\text { Pimenta } \\
\text { officinalis }\end{array}$ \\
\hline C1442 & Eucalyptus & $4.3 \mathrm{a}$ & $3.7 \mathrm{bcd}$ \\
C1440 & Eucalyptus & $3.9 \mathrm{a}$ & $4.5 \mathrm{bcd}$ \\
C1345 & Eucalyptus & $1.8 \mathrm{~b}$ & $3.3 \mathrm{bcd}$ \\
C920 & Gmelina & $1.3 \mathrm{~b}$ & $6.0 \mathrm{bcd}$ \\
C1905 & Colocasia & $1.3 \mathrm{~b}$ & $1.9 \mathrm{bcd}$ \\
C1865 & Colocasia & $1.1 \mathrm{~b}$ & $1.4 \mathrm{~cd}$ \\
C1926 & Colocasia & $0.8 \mathrm{~b}$ & $1.5 \mathrm{~cd}$ \\
C1782 & Ficus & $0.7 \mathrm{~b}$ & $4.7 \mathrm{bcd}$ \\
C1558 & Mangifera & $0.7 \mathrm{~b}$ & $4.3 \mathrm{bcd}$ \\
C1899 & Ficus & $\mathrm{NT}$ & $18.0 \mathrm{a}$ \\
C918 & Gmelina & $\mathrm{NT}$ & $7.7 \mathrm{~b}$ \\
C1857 & Ficus & $\mathrm{NT}$ & $7.2 \mathrm{bc}$ \\
C925 & Gmelina & NT & $6.4 \mathrm{bcd}$ \\
C994 & Mangifera & $\mathrm{NT}$ & $4.3 \mathrm{bcd}$ \\
C1688 & Mangifera & $\mathrm{NT}$ & $1.9 \mathrm{bcd}$ \\
Control & .. & $0.3 \mathrm{~b}$ & $0.7 \mathrm{~d}$ \\
\hline
\end{tabular}

${ }^{\mathrm{z}}$ Numbers within a column followed by the same letter are not significantly different $(P<0.05)$ based on Fisher's protected least significant difference. $\mathrm{NT}=$ the isolate was not tested.

TABLE 4. Average length of xylem discoloration and percent mortality in exotic Ficus carica (family Moraceae) plants inoculated in a nursery and growthchamber experiment with Brazilian isolates of Ceratocystis fimbriata

\begin{tabular}{|c|c|c|c|c|}
\hline \multirow[b]{2}{*}{ Isolate no. } & \multirow[b]{2}{*}{ Host } & \multicolumn{2}{|c|}{ Nursery } & \multirow{2}{*}{$\begin{array}{c}\text { Growth chamber } \\
\text { Xylem discoloration }(\mathrm{cm})^{\mathrm{y}}\end{array}$} \\
\hline & & Xylem discoloration $(\mathrm{cm})^{\mathrm{y}}$ & Mortality $(\%)^{\mathrm{z}}$ & \\
\hline C918 & Gmelina & $19.7 \mathrm{a}$ & 66.7 & 2.6 bcde \\
\hline C1782 & Ficus & $19.5 \mathrm{a}$ & 16.7 & $3.6 \mathrm{ab}$ \\
\hline $\mathrm{C} 1440$ & Eucalyptus & $15.9 \mathrm{ab}$ & 33.3 & $2.1 \mathrm{cde}$ \\
\hline C920 & Gmelina & $15.7 \mathrm{ab}$ & 66.7 & $3.9 \mathrm{ab}$ \\
\hline C1857 & Ficus & $15.5 \mathrm{ab}$ & 50 & $4.1 \mathrm{a}$ \\
\hline C1899 & Ficus & $15.0 \mathrm{ab}$ & 66.7 & $2.9 \mathrm{abc}$ \\
\hline C 1558 & Mangifera & $14.3 \mathrm{ab}$ & 33.3 & $1.9 \mathrm{cdef}$ \\
\hline $\mathrm{C} 925$ & Gmelina & $14.2 \mathrm{ab}$ & 66.7 & $3.1 \mathrm{abc}$ \\
\hline C994 & Mangifera & $12.8 \mathrm{ab}$ & 20 & $1.4 \mathrm{ef}$ \\
\hline $\mathrm{C} 1442$ & Eucalyptus & $11.1 \mathrm{ab}$ & 33.3 & $1.5 \mathrm{def}$ \\
\hline C1345 & Eucalyptus & $9.2 \mathrm{bc}$ & 0 & $2.9 \mathrm{abcd}$ \\
\hline C1688 & Mangifera & $8.7 \mathrm{bc}$ & 0 & 2.8 abcde \\
\hline C1905 & Colocasia & $8.1 \mathrm{bc}$ & 33.3 & $3.0 \mathrm{abc}$ \\
\hline C1865 & Colocasia & $7.8 \mathrm{bc}$ & 0 & 2.2 cde \\
\hline C1926 & Colocasia & $7.0 \mathrm{bc}$ & 0 & 1.4 ef \\
\hline Control & $\ldots$ & $0.5 \mathrm{c}$ & 0 & $0.6 \mathrm{f}$ \\
\hline
\end{tabular}

y Numbers within a column followed by the same letter are not significantly different $(P<0.05)$ based on Fisher's protected least significant difference.

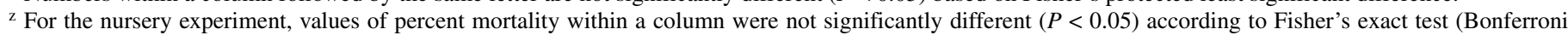
adjusted $\alpha=0.0033$ ). There was no mortality in the growth-chamber experiments. 
Fig isolate C1899 (population FicSP3, ITS haplotype ITS1) caused the greatest xylem discoloration in Pimenta officinalis (Table 5). The other two isolates causing significantly greater xylem discoloration in $P$. officinalis compared with the control were C918 from Gmelina and C1857 from fig (population FicSP3; ITS haplotype ITS1).

Anacardiaceae host plants. ANOVA indicated that there was significant variation in the length of xylem discoloration among the isolates inoculated in all three species of Anacardiaceae (mango, A. occidentale, and $S$. terebinthifolius) in the nursery $(F=29.26, P<0.0001 ; F=3.51, P=0.0002$; and $F=2.03, P=$ 0.0285 ; respectively). Only three isolates caused significantly greater xylem discoloration in mango compared with the control, but these three isolates were from three different hosts (Table 6). Mango isolate C1558 (ManRJ2, ITS9) caused the greatest xylem discoloration but mango isolates C994 and C1688 (ManSP1, ITS10 and ManSP1, ITS14, respectively) did not cause more discoloration than in the controls (Table 6). Gmelina isolate C920 (followed by mango isolate C994 and the three inhame isolates) caused the greatest discoloration in the native host S. terebinthifolius. Only one isolate, C1899 from fig, caused significantly greater xylem discoloration than the control in A. occidentale in the nursery experiment.

The only species from the Anacardiaceae family that was inoculated in the growth chamber was cashew, A. occidentale. Data from the two inoculation experiments, however, could not be combined because the variances of the two experiments were not homogeneous. Xylem discoloration varied significantly by isolate $(F=2.07, P=0.035)$ and experiment $(F=54.48, P<0.0001)$ and there was significant isolate-experiment interaction $(F=4.33$, $P<0.0001)$. Only in experiment 2 was there significant variation in the length of xylem discoloration among the isolates $(F=5.32$, $P=0.0002)$. Results of the protective LSD multiple-range test indicated that the four isolates causing xylem discoloration greater than the control were from four different hosts (Table 6). Eucalyptus isolate $\mathrm{C} 1442$ caused the most xylem discoloration in the second experiment of $A$. occidentale but this same isolate caused the least amount of xylem discoloration in mango, the other species of Anacardiaceae inoculated in the nursery experiment. Successful reisolation of the fungus was $\geq 50 \%$ for all isolates inoculated into cashew in the growth-chamber experiments, except for inhame isolate $\mathrm{C} 1865$, which was not reisolated.

\section{DISCUSSION}

Isolates of $C$. fimbriata from Brazil varied in aggressiveness to cultivated hosts, and isolates from a given host tended to be the most aggressive isolates to that host; however, clear patterns of host specialization were not evident. Rather, the tested isolates showed a continuous range in the extent of vascular discoloration in most of the inoculated hosts. On some hosts, there was almost as much variation in aggressiveness among isolates from within a sampled population or lineage as among populations or lineages.

Isolates from well-defined and highly differentiated populations with little or no variation in microsatellite alleles (8) were polyphyletic based on the ITS-rDNA sequence analysis. These results and others $(1,17,32)$ indicate that ITS-rDNA sequences have limited phylogenetic value within the Latin American clade of C. fimbriata, apparently because of their numerous and hypervariable indels, especially in the ITS-1 region. A relatively high homoplasy index (0.3371) for the most parsimonious tree suggests that the indels change too quickly within populations to be of phylogenetic value.

The Brazilian isolates appeared to be closely related to each other and to $C$. fimbriata sensu stricto based on the analysis of MAT1-2 sequences, which grouped the Gmelina isolates together, the inhame isolates together, the fig isolates together, and the Bahian Eucalyptus isolates together, with at least moderate bootstrap support for each of these four lineages. These four MAT1-2 haplotypes also came from four discrete populations based on microsatellite analyses (8). Isolates from mango had differing MAT1-2 haplotypes, some of which were identical to the inhame, fig, or Eucalyptus haplotypes. Only 14 parsimonyinformative characters were found among the $1,133 \mathrm{bp}$ of the aligned MAT1-2 dataset of the Brazilian isolates of $C$. fimbriata and the sweet potato pathogen, which may have originated in northern South America (6), suggesting that these populations were recently derived from a common ancestor, perhaps something similar to $C$. cacaofunesta, which is thought to be native to the Upper Amazon (4,5). Consistent with the MAT1-2 analysis, tester strains from Gmelina, inhame, fig, Eucalyptus, and mango were interfertile in mating tests with each other and with a sweet potato tester but they were not interfertile with testers of $C$. cacaofunesta and C. platani (8).

TABLE 6. Average length of xylem discoloration (cm) in Anacardiaceae spp. exotic (Mangifera indica) or native (Schinus terebinthifolius and Anacardium occidentale) to Brazil inoculated in nursery and growth-chamber (A. occidentale only) experiments ${ }^{y}$

\begin{tabular}{|c|c|c|c|c|c|c|}
\hline \multirow[b]{3}{*}{ Isolate no. } & \multirow[b]{3}{*}{ Host } & \multirow{2}{*}{\multicolumn{2}{|c|}{ Nursery }} & \multicolumn{3}{|c|}{ A. occidentale } \\
\hline & & & & \multirow[b]{2}{*}{ Nursery } & \multicolumn{2}{|c|}{ Growth chamber $^{2}$} \\
\hline & & M. indica & S. terebinthifolius & & Exp. 1 & Exp. 2 \\
\hline C920 & Gmelina & $4.3 \mathrm{~b}$ & $7.7 \mathrm{a}$ & $2.4 \mathrm{bc}$ & 1.9 & $3.5 \mathrm{de}$ \\
\hline $\mathrm{C} 1440$ & Eucalyptus & $3.4 \mathrm{bc}$ & $2.4 \mathrm{bc}$ & $1.5 \mathrm{~cd}$ & 3.1 & $3.6 \mathrm{de}$ \\
\hline $\mathrm{C} 1345$ & Eucalyptus & $2.7 \mathrm{~cd}$ & $2.7 \mathrm{bc}$ & $1.6 \mathrm{bcd}$ & 1.5 & NT \\
\hline C1688 & Mangifera & $2.5 \mathrm{cde}$ & $4.2 \mathrm{abc}$ & $1.5 \mathrm{~cd}$ & 2.7 & $7.2 a b c$ \\
\hline C925 & Gmelina & $1.9 \mathrm{defg}$ & NT & $2.4 \mathrm{bc}$ & 2.0 & $3.9 \mathrm{de}$ \\
\hline C1899 & Ficus & $1.8 \mathrm{defg}$ & $3.6 \mathrm{bc}$ & $3.7 \mathrm{a}$ & 2.5 & $3.5 \mathrm{de}$ \\
\hline C994 & Mangifera & $1.7 \mathrm{defg}$ & $5.4 \mathrm{ab}$ & $2.4 \mathrm{bc}$ & 2.4 & $2.4 \mathrm{de}$ \\
\hline C1926 & Colocasia & $1.6 \mathrm{defg}$ & $4.3 \mathrm{~b}$ & $1.7 \mathrm{bcd}$ & NT & NT \\
\hline C918 & Gmelina & $1.5 \mathrm{defg}$ & $3.5 \mathrm{bc}$ & $2.5 \mathrm{~b}$ & 2.5 & $3.9 \mathrm{cde}$ \\
\hline C1857 & Ficus & $1.3 \mathrm{efg}$ & $2.8 \mathrm{bc}$ & $1.5 \mathrm{~cd}$ & 2.9 & NT \\
\hline $\mathrm{C} 1865$ & Colocasia & $1.1 \mathrm{fg}$ & $5.6 \mathrm{ab}$ & $1.5 \mathrm{bcd}$ & 0.8 & $1.8 \mathrm{e}$ \\
\hline
\end{tabular}

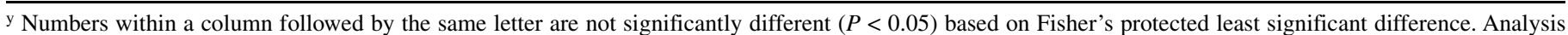
of variance indicated that there was no significant variation among the isolates in the first Anacardium experiment in the growth chamber. NT $=$ the isolate was not tested.

z There was no homogeneity of variances for the first and second experiments; therefore, the data for the two experiments were analyzed separately. 
The inoculation results were largely consistent with those of earlier inoculation experiments, which used some of the same isolates. Baker et al. (1) also found that some Eucalyptus and Gmelina isolates caused greater discoloration in their respective hosts than did isolates from mango, but Eucalyptus and Gmelina isolates were also aggressive on other hosts. Some, but not all, of the isolates from fig and inhame were among the most aggressive on their respective hosts in our inoculations. Thorpe et al. (32) also found that inhame isolates were more aggressive than isolates from fig and mango on the family Araceae.

In addition to being genetically variable, isolates from mango varied greatly in aggressiveness to mango and other hosts. An isolate from mango collected from a genetically differentiated population (ManRJ2) in northeastern Rio de Janeiro state was particularly aggressive to mango, as was found with other isolates from this region (1). Isolates from this region are also aggressive on sugar apple, Annona squamosa (30), which has been recorded as a host only in this region of Brazil. It is noteworthy that inhame isolates (population ColSP2) that had the same MAT1-2 haplotype as the ManRJ2 population were not pathogenic to mango. Thus, MAT1-2 haplotype does not necessarily correlate with aggressiveness to a particular host.

It was hypothesized that the strains of the fungus that are aggressive on a particular cultivated host would be more aggressive or host specialized on native plants of the same family but the results of the inoculation experiments lead to rejection of that hypothesis. A possible exception was the three isolates from Gmelina, which were the most aggressive on the exotic $G$. arborea and also tended to be more aggressive on species of Verbenaceae native to Brazil. These Gmelina isolates were the most geographically isolated of the isolates studied, and they may represent a cryptic species, in spite of interfertility with other Brazilian isolates of C. fimbriata (8). Unfortunately, all of the Gmelina isolates came from trees in a small section of a single plantation, and this population from the Lower Amazon needs further study (8).

Strains on inhame across Brazil may have originated from São Paulo (14,32). Inhame isolates from São Paulo were related to each other in microsatellite analyses (8) and MAT1-2 sequences, and some inhame isolates appeared to be particularly aggressive on inhame and other species of Araceae in an earlier study (32). However, an isolate from Eucalyptus (C1345) was also among the most aggressive isolates on inhame in our tests. This plant is propagated from corms, which $C$. fimbriata and other related Ceratocystis spp. readily colonize and rot (32). Thus, propagation through infected corms could lead to selection of particularly aggressive strains of the pathogen and movement of these strains to new areas.

Edible fig was very susceptible in our inoculation studies in the nursery, which used a grafted, commercial cultivar from São Paulo. Inoculations of seedlings from a noncommercial fig in the growth chamber showed lower susceptibility. There was substantial variation in aggressiveness among isolates on fig but fig isolates did not appear to be more aggressive than other isolates on this host. The fig isolates originated from a small commercial growing area in São Paulo (33), the only place in Latin America where Ceratocystis spp. cause disease in fig. The strains in this region may have been introduced on nursery stock because the isolates are almost identical to each other based on microsatellite analysis (8). Alternatively, the population of $C$. fimbriata in that small region may be natural but with limited genetic variation. The fig isolates share a MAT1-2 haplotype with two mango isolates from São Paulo, isolates C994 and C1847, but isolate C994 differed from the fig isolates in aggressiveness to several hosts.

Two of the three isolates from Eucalyptus were particularly aggressive to Eucalyptus spp. based on the extent of xylem discoloration, as has been found in earlier inoculations $(1,39)$. These isolates were from the region of Bahia where Ceratocystis wilt of Eucalyptus was first recognized, and it is believed that Eucalyptus stains from Bahia, and perhaps Minas Gerais, have been moved to other regions of Brazil and to Uruguay and Africa in symptomless Eucalyptus cuttings (8). Zauza et al. (39) tested 18 commercial clones of Eucalyptus grandis $\times$ E. urophylla using two Eucalyptus isolates of $C$. fimbriata and found variable susceptibility of the clones, ranging from highly susceptible to showing no more discoloration than the control. Many of the clones differed in their susceptibility to the two isolates. Thus, breeding or selection for resistance will need to include more than one isolate of $C$. fimbriata from Eucalyptus spp. Indeed, a high level of variation in aggressiveness within and among populations of $C$. fimbriata in Brazil is a major impediment to breeding and selection for resistance in any crop, especially mango (28).

Compared with isolates from other hosts, mango isolates of $C$. fimbriata show substantial variation in ITS-rDNA and MAT1-2 sequences, in microsatellite markers (8), and in aggressiveness to mango in inoculation studies (1). Fifteen cultivars of mango varied greatly in resistance to root infection and stem infection to two isolates of $C$. fimbriata, and a cultivar once considered resistant to Ceratocystis wilt in São Paulo later proved susceptible to another strain of the fungus in another region of São Paulo (28). C. fimbriata can cause substantial mortality of mango in plantations, gardens, and street trees in Brazil, the only country where Ceratocystis wilt on mango had been recorded until recently (2). Rosetto and Ribeiro (27) suggested that mango strains of $C$. fimbriata were being distributed throughout Brazil in infected seedlings, grafted cuttings, and accompanying soil from nurseries in São Paulo. A population of C. fimbriata on mango street trees in Mato Grosso do Sul, Brazil had the same microstatellite alleles as isolate C1847, a mango isolate from São Paulo, and it was suggested that the pathogen was introduced to Mato Grosso do Sul from a nursery in São Paulo (8). Other mango strains from São Paulo may have been introduced to Oman and Pakistan in grafted mango plants or accompanying soil $(8,34)$. Movement of Brazilian strains of $C$. fimbriata in nursery material, cuttings, and corms appears to be an increasing problem.

The sweet potato strain, on which the species name $C$. fimbriata is based, is likely an anomaly of human cultivation and propagation of sweet potato, and its aggressiveness to sweet potato appears to be unique $(1,6)$. However, if this unique aggressiveness and differing ITS-rDNA sequence are the sole basis for distinguishing new species in the complex, then $C$. fimbriata sensu stricto would be represented by only a single genotype. Also, if each genetically distinct population of $C$. fimbriata is to be considered a new species without a distinguishing phenotype (13), then dozens or hundreds of new species would likely be needed to name all of the genetically distinct populations in Latin America $(8,20)$. Marin et al. (20) were unable to morphologically distinguish the genotypes of Colombian isolates of $C$. fimbriata, and the isolates showed a range of aggressiveness to coffee plants. Lacking a more robust phylogeny to distinguish the Brazilian populations from the sweet potato strain, and with no clear phenotype to distinguish among the Brazilian haplotypes, we consider the Brazilian populations, other than $C$. cacaofunesta, to be $C$. fimbriata sensu stricto. Interfertility among Brazilian isolates and the sweet potato strain further supports recognition of the Brazilian populations as $C$. fimbriata sensu stricto. Other recently described species in the Latin American clade (C. colombiana, $C$. papillata, and $C$. neglecta from Colombia and $C$. fimbriatomima from Venezuela) are probably distinct from Brazilian populations of $C$. fimbriata $(26,35,36)$; ITS and MAT1-2 sequences of Colombian isolates from citrus and coffee are distinct from those of Brazilian isolates of $C$. fimbriata (T. C. Harrington, unpublished). However, C. manginecans from Oman and Pakistan appears to be a strain of $C$. fimbriata that was introduced from Brazil on mango plants or accompanying soil $(8,34)$. 
The hypothesis of host-specialized, cryptic species in Brazil was not supported by the phylogenetic analyses or the inoculation results. The alternative hypothesis, that natural populations of $C$. fimbriata vary greatly in aggressiveness to various hosts by combinations of numerous, quantitative traits (24), is more likely. In their native habitat on native hosts, members of the $C$. fimbriata complex are thought to be relatively nonaggressive wound colonizers, and intraspecific variation in aggressiveness to native hosts can be seen in seedling inoculation experiments (17). There are likely numerous fitness traits that determine success on the various hosts, including ability to extensively colonize the xylem in the vicinity of the wound, and such quantitative traits may be expected to vary greatly in natural populations of plant pathogens (24).

Baker et al. (1) found a wide range of aggressiveness among Brazilian isolates of $C$. fimbriata to several cultivated hosts, especially to the highly susceptible legume Crotolaria juncea. The results of Marin et al. (20) also support the concept that quantitative traits determine aggressiveness of isolates of Ceratocystis fimbriata to cultivated hosts. A continuous range from small cankers and no mortality to large cankers with nearly $100 \%$ mortality was found among 50 isolates of $C$. fimbriata from Colombian soils and coffee plants when inoculated into a commercial cultivar of coffee. Many of the most aggressive strains on coffee were from the northwest coffee-growing region of Colombia, where native hosts of $C$. fimbriata are used for shade in coffee plantations, and large and diverse pathogen populations may be expected (20). No native hosts are known for $C$. fimbriata in the Atlantic Coastal regions of Brazil; therefore, the only studied populations are those where strains have caused substantial disease in exotic, cultivated hosts. Thus, the isolates studied do not necessarily represent the natural variation found in Brazilian populations. Much more work is needed with natural populations of $C$. fimbriata to understand the ecology and evolution of this important pathogen.

Variation in aggressiveness presents a challenge for efforts in breeding and selection for resistance. Selection for strains with particular aggressiveness to some crops in vegetatively propagated material or in accompanying soil is another serious concern. To date, only Brazilian strains of $C$. fimbriata have been shown to be serious pathogens on Eucalyptus spp. and mango. Movement of these strains on propagative material continues to be a threat for other regions of Brazil and other countries $(8,9)$, as has been seen with movement of other members of the $C$. fimbriata complex, such as $C$. cacaofunesta, $C$. platani, and $C$. populicola $(4,7,17,23)$.

\section{ACKNOWLEDGMENTS}

This research was supported by the National Science Foundation through grants DEB-987065 and DEB-0128104 and by the Conselho Nacional de Desenvolvimento Científíco e Tecnológico (CNPq). We thank J. Steimel for technical assistance; E. Zauza for assistance in inoculating plants in Brazil; and J. P. Pimentel, P. S. Brioso, and E. Furtado for providing invaluable assistance in collection of isolates.

\section{LITERATURE CITED}

1. Baker C. J., Harrington T. C., Krauss, U., and Alfenas, A. C. 2003. Genetic variability and host specialization in the Latin American clade of Ceratocystis fimbriata. Phytopathology 93:1274-1284.

2. CAB International. 2005. Ceratocystis fimbriata (original text prepared by T. C. Harrington). In: Crop Protection Compendium. CAB International, Wallingford, UK.

3. DeScenzo, R. A., and T. C. Harrington. 1994. Use of (CAT) $)_{5}$ as a DNA fingerprinting probe for fungi. Phytopathology 84:534-540.

4. Engelbrecht, C. J., Harrington, T. C., and Alfenas, A. C. 2007. Ceratocystis wilt of cacao-a disease of increasing importance. Phytopathology 97:1648-1649.

5. Engelbrecht, C. J., Harrington, T. C., Alfenas , A. C., and Suarez, C. 2007.
Genetic variation of populations of the cacao wilt pathogen, Ceratocystis cacaofunesta. Plant Pathol. 56:923-933.

6. Engelbrecht, C. J. B., and Harrington, T. C. 2005. Intersterility, morphology, and taxonomy of Ceratocystis fimbriata on sweet potato, cacao, and sycamore. Mycologia 97:57-69.

7. Engelbrecht, C. J. B., Harrington, T. C., Steimel, J., and Capretti, P. 2004. Genetic variation in eastern North American and putatively introduced populations of Ceratocystis fimbriata f. platani. Mol. Ecol. 13:2995-3005.

8. Ferreira, E. M., Harrington, T. C., Thorpe, D. J., and Alfenas, A. C. 2010. Genetic diversity and interfertility among highly differentiated populations of Ceratocystis fimbriata in Brazil. Plant Pathol. 59:721-735.

9. Harrington, T. C. 2000. Host specialization and speciation in the American wilt pathogen Ceratocystis fimbriata. Fitopatol. Bras. 25:262263.

10. Harrington, T. C. 2009. The genus Ceratocystis. Where does the oak wilt fungus fit? Pages 21-35 in: Proc. 2nd Natl. Oak Wilt Symp. Austin, TX. D. N. Appel and R. F. Billings, eds. Texas For. Serv. Publ. 166.

11. Harrington T. C., and McNew, D. L. 1997. Self-fertility and uni-directional mating-type switching in Ceratocystis coerulescens, a filamentous ascomycete. Curr. Genet. 32:52-59.

12. Harrington, T. C., McNew, D. M., Steimel, J., Hofstra, D., and Farrell, R. 2001. Phylogeny and taxonomy of the Ophiostoma piceae complex and the Dutch elm disease fungi. Mycologia 93:110-135.

13. Harrington, T. C., and Rizzo, D. M. 1999. Defining species in the fungi. Pages 43-71 in: Structure and Dynamics of Fungal Populations. J. J. Worrall, ed. Kluwer Press, Dordrecht, The Netherlands.

14. Harrington, T. C., Thorpe, D. J., Marinho, V. L. A., and Furtado, E. L. 2005. First report of black rot of Colocasia esculenta caused by Ceratocystis fimbriata in Brazil. Fitopatol. Bras. 30:88-89.

15. Heath, R. N., Wingfield, M. J., Wingfield, B. D., Meke, G., Mbaga, A., and Roux, J. 2009. Ceratocystis species on Acacia mearnsii and Eucalyptus spp. in eastern and southern Africa including six new species. Fungal Divers. 34:41-67.

16. Iton, E. F., and Conway, G. R. 1961. Studies on a wilt disease of cacao at River Estate III. Some aspects of the biology and habits of Xyleborus spp. and their relation to disease transmission. Pages 59-65 in: Annual Report on Cacao Research, 1959-1960. Imperial College of Tropical Agriculture, St. Augustine, Trinidad.

17. Johnson, J. A., Harrington, T. C., and Engelbrecht, C. J. B. 2005. Phylogeny and taxonomy of the North American clade of the Ceratocystis fimbriata complex. Mycologia 97:1067-1092.

18. Laia, M. L., Alfenas, A. C., and Harrington, T. C. 2000. Isolation, detection in soil, and inoculation of Ceratocystis fimbriata, causal agent of wilting, die-back and canker in Eucalyptus. (Abstr.). Fitopatol. Bras. $25: 384$.

19. Leather, R. I. 1966. A canker and wilt disease of pimento (Pimenta officianalis) caused by Ceratocystis fimbriata in Jamaica. Trans. Br. Mycol. Soc. 49:213-218.

20. Marin, M., Castro, B., Gaitan, A., Preisig, O., Wingfield, B. D, and Wingfield, M. J. 2003. Relationships of Ceratocystis fimbriata isolates from Colombian coffee-growing regions based on molecular data and pathogenicity. J. Phytopathol. 151:395-405.

21. Moller, W. J., and DeVay, J. E. 1968. Carrot as a species-selective medium for Ceratocystis fimbriata. Phytopathology 58:123-124.

22. Muchovej, J. J., Albuquerque, F. C., and Ribeiro, G. T. 1978. Gmelina arborea-a new host of Ceratocystis fimbriata. Plant Dis. Rep. 62:717719.

23. Ocasio-Morales, R. G., Tsopelas, P., and Harrington, T. C. 2007. Origin of Ceratocystis platani on native Platanus orientalis in Greece and its impact on natural forests. Plant Dis. 91:901-904.

24. Pariaud, B., Ravigné, V., Halkett, F., Goyeau, H., Carlier, J., and Lannou, C. 2009. Aggressiveness and its role in the adaptation of plant pathogens. Plant Pathol. 58:409-424.

25. Ribeiro, I. J. A., and Coral, F. J. 1968. Estudo preliminary da ação do fungo Ceratocystis fimbriata Ell. and Halst., causador da seca da mangueira (Mangifera indica L.), sobre cacaueiros (Theobroma cacao L.). Bragantia 27:87-89.

26. Rodas, C. A., Roux, J., van Wyk, M., Wingfield, B. D., and Wingfield, M. J. 2008. Ceratocystis neglecta sp. nov., infecting Eucalyptus trees in Colombia. Fungal Divers. 28:73-84.

27. Rossetto, C. J., and Ribeiro, I. J. A. 1990. Seca da mangueira. XII. Recomendações de controle. Rev. Agric. 65:173-180.

28. Rossetto, C. J., Ribeiro, I. J. A., Igue, T., and Gallo, P. B. 1996. Seca-damangueira: XV. Resistência varietal a dois isolados de Ceratocystis fimbriata. Bragantia 55:117-121.

29. Roux, J., Harrington, T. C., Steimel, J. P., and Wingfield, M. J. 2001. Genetic variation in the wattle wilt pathogen Ceratocystis albofundus. Mycoscience 42:327-332.

30. Silveira, S. F., Harrington, T. C., Mussi-Dias, V., Engelbrecht, C. J. B., Alfenas, A. C., and Silva, C. R. 2006. Annona squamosa, a new host of 
Ceratocystis fimbriata. Fitopatol. Bras. 31:382-385.

31. Swofford, D. L. 1998. PAUP*. Phylogenetic Analysis Using Parsimony (*and Other Methods), Version 4. Sinauer Associates, Sunderland, MA

32. Thorpe, D. J., Harrington, T. C., and Uchida, J. Y. 2005. Pathogenicity, internal transcribed spacer-rDNA variation, and human dispersal of Ceratocystis fimbriata on the family Araceae. Phytopathology 95:316-323.

33. Valarini, P. J., and Tokeshi, H. 1980. Ceratocystis fimbriata, causal agent of fig dieback, and its control. Summa Phytopathol. 6:102-106.

34. Van Wyk, M., Al Adawi, A. O., Khan, I. A., Deadman, M. L., Al Jahwari, A. A., Wingfield, B. D., Ploetz, R., and Wingfield, M. J. 2007. Ceratocystis manginecans sp. nov., causal agent of a destructive mango wilt disease in Oman and Pakistan. Fungal Divers. 27:213-230.

35. Van Wyk, M., Wingfield, B. D., Marin, M., and Wingfield, M. J. 2010. New Ceratocystis species infecting coffee, cacao, citrus and native trees in Colombia. Fungal Divers. 40:103-117.
36. Van Wyk, M., Wingfield, B. D., Mohali, S., and Wingfield, M. J. 2009. Ceratocystis fimbriatomima, a new species in the C. fimbrirata sensu lato complex isolated from Eucalyptus trees in Venezuela. Fungal Divers. 34:175-185

37. Witthuhn, R. C., Harrington, T. C., Steimel, J. P., Wingfield, B. D., and Wingfield. M. J. 2000. Comparison of isozymes, rDNA spacer regions, and MAT-2 DNA sequences as phylogenetic characters in the analysis of the Ceratocystis coerulescens complex. Mycologia 92:447-452.

38. Witthuhn, R. C., Harrington, T. C., Wingfield, B. D., Steimel, J., and Wingfield, M. J. 2000. Deletion of the MAT-2 mating type gene during uni-directional mating type switching in Ceratocystis. Curr. Genet. 38:4852.

39. Zauza, E. A. V., Alfenas, A. C., Harrington, T. C., Mizubuti, E. S., and Silva, J. F. 2004. Resistance of Eucalyptus clones to Ceratocystis fimbriata. Plant Dis. 88:758-760. 